\title{
RECENT LEGISLATIVE AND REGULATORY DEVELOPMENTS OF INTEREST TO OIL AND GAS LAWYERS
}

\author{
LAURA M. DISANTO, FRANCES FERGUSON \\ AND PATRICIA H. FORREST*
}

The purpose of this paper is to provide a brief review of recent legislative and regulatory developments of particular interest to oil and gas lawyers. In addition to reporting on recent changes in statutes and regulations, and recent decisions and published policy statements of administrative bodies, the paper also discusses a number of legislative and regulatory developments which are still evolving. In order to place some limit on the scope of the article. federal and Alberta legislative and regulatory developments are reported as well as certain noteworthy developments in British Columbia and Saskatchewan.

\section{TABLE OF CONTENTS}

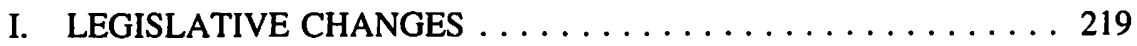

A. FEDERAL LEGISLATION $\ldots \ldots \ldots \ldots \ldots \ldots \ldots \ldots 219$

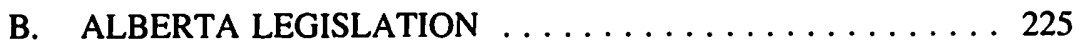

C. BRITISH COLUMBIA LEGISLATION $\ldots \ldots \ldots \ldots \ldots 235$

D. SASKATCHEWAN LEGISLATION $\ldots \ldots \ldots \ldots \ldots \ldots 238$

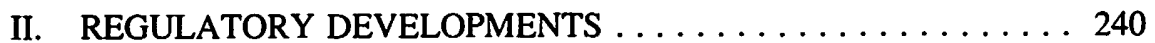

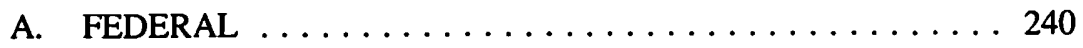

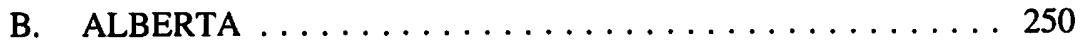

C. BRITISH COLUMBIA $\ldots \ldots \ldots \ldots \ldots \ldots \ldots \ldots$

\section{LEGISLATIVE CHANGES}

\section{A. FEDERAL LEGISLATION}

\section{Statutes}

(a) Bank Act, S.C. 1991 , c. 46

This Act replaces the Bank Act, R.S.C. 1985, c. B-1. Section 426 of the new Bank Act contains the provisions governing loans that a bank may make on the security of hydrocarbons or minerals or an interest in them. It was assented to December 13, 1991 with proclamation proposed for June 1, 1992.

The authors are members of the law department of Imperial Oil Resources Limited. The authors wish to express their appreciation to other members of the law department of Imperial Oil Resources Limited for their assistance in the preparation of this article. 
(b) Canadian Laws Offshore Applications Act, S.C. 1990, c. 44

This Act was discussed in last year's article.' Section 7, being the application of provincial laws in the offshore, has not been proclaimed as of April 15, 1992. The rest of the Act was in force February 4, 1991.

\section{(c) Canadian Polar Commission Act, S.C. 1991, c. 6}

This Act establishes the Canadian Polar Commission whose purpose is "to promote the development and dissemination of knowledge in respect of the polar regions" including "enhancing Canada's international profile as a circumpolar nation by fostering international cooperation in the advancement of knowledge in respect of the polar regions."2 The Commission shall be managed by a Board of Directors of up to twelve members including a Chairperson and two Vice-Chairpersons with its head office in the National Capital Region. Proclaimed in force as of September 9, 1991.

(d) An Act to Amend the Federal Court Act, The Crown Liability Act, The Supreme Court Act and Other Acts in Consequence Thereof, S.C. 1990, c. 8

This Act amends the Federal Court Act, R.S.C. 1985, c. F-7. The changes clarify the Federal Court's role in supervising federal tribunals, including the National Energy Board ("NEB"), and clarify the grounds for challenging tribunal decisions. There are consequential amendments to the Canada Petroleum Resources Act ${ }^{3}$ the Northern Inland Waters Act, ${ }^{4}$ the Northern Pipeline Act ${ }^{5}$ and the Petroleum Incentives Program Act. ${ }^{6}$ The amendments were proclaimed in force as of February 1, 1992.

\section{(e) Federal Real Property Act, S.C. 1991, c. 50}

This Act governs the acquisition, administration and disposition of real property by the government of Canada. It repeals the Public Land Grants Act. ${ }^{7}$ There are consequential amendments to numerous statutes including the Canada-Newfoundland Atlantic Accord Implementation Act ${ }^{8}$ the Canada-Nova Scotia Offshore Petroleum Resources Accord Implementation Act, ${ }^{9}$ the Northern Inland Waters Act, ${ }^{10}$ the Northern Pipeline Act ${ }^{11}$ and the Oil and Gas Production and Conservation Act. ${ }^{12}$ These amendments are to

\footnotetext{
1. L.M. DiSanto, F. Ferguson and P.H. Forrest, "Recent Legislative and Regulatory Developments of Interest to Oil and Gas Lawyers (1992) 30 Alta. L. Rev. 379.

2. Canadian Polar Commission Act, S.C. 1991, c. 6, s. 4(f).

R.S.C. 1985 (2nd Supp.), c. 36.

R.S.C. 1985 , c. $\mathrm{N}-25$.

R.S.C. 1985 , c. $\mathrm{N}-26$.

R.S.C. 1985 , c. P.-13.

R.S.C. 1985 , c. P-30.

S.C. 1987 , c. 3 .

S.C. 1990 , c. 28 .

Supra note 4.

Supra note 5.

R.S.C. 1985 , c. $0-7$.
} 
eliminate references to the Public Land Grants Act and to conform wording to that used in the new legislation. Royal Assent was given December 17, 1991 but as of April 15, 1992, it had not been proclaimed in force.

(f) National Energy Board Amendment Act, S.C. 1991, c. 7

This Act amends the National Energy Board Act ${ }^{13}$ to provide for the head office of the NEB to be in Calgary, Alberta. It was assented to June 21, 1991 and proclaimed in force November 1, 1991.

\section{Regulations}

The Regulations are described under the name of the Act they are made pursuant to.

(a) Arctic Waters Pollution Prevention Act, R.S.C. 1985, c. A-12

Arctic Shipping Pollution Prevention Regulations, amendment, SOR/91-483

These Regulations amend the Arctic Shipping Pollution Prevention Regulations, C.R.C., c. 353. The amendment permits an entry date extension in the years 1991 to 1993 for an Arctic Class 3 ship in zones 1, 6 and 13 as specified in the Regulations. The anticipated impact of this amendment is that by extending the shipping season there will be an increased opportunity to ship products to market in a year from the oil terminal on Cameron Island. There are also minor consequential amendments. This came in effect on August 14, 1991.

(b) Canadian Exploration Incentive Program Act, R.S.C. 1985 (4th Supp.), c. 27

Canadian Exploration Incentive Program Regulations, amendment, SOR/91-452

These Regulations made amendments consequential to the termination of the Canadian Exploration Incentive Program and the establishment of a grandfathering period, and other amendments relating to the administration of the program. There are provisions prescribing eligible exploration expenses from February 20, 1990: these expenses must be incurred pursuant to a grandfathered flow-through share agreement. A regular application for incentives for expenses incurred in 1991 could not be made after August 31, 1991 and no supplemental application could be made after December 31, 1991. These Regulations were in effect July 10, 1991. 
(c) Canada Petroleum Resources Act, R.S.C. 1985 (2nd Supp.), c. 36

\section{Frontier Lands Petroleum Royalty Regulations, SOR/92-26}

These Regulations replace the Frontier Lands Petroleum Royalty Regulations, 1987, ${ }^{14}$ which were promulgated as an interim measure. All areas in the North are subject to these Regulations except: the Normal Wells field, the Pointed Mountain field and the Kotaneelee field and areas subject to the Inuvialuit Final Agreement, where the Inuvialuit have been granted subsurface rights. These Regulations also apply to Hudson Bay, the West Coast offshore and areas in the East Coast offshore not under an Accord regime.

The federal government says its policy intent under these royalty regulations is to limit the royalty burden during early production and on marginal projects, and to ensure an equitable sharing of revenues between government and industry after the initial investment has been recovered.

Before payout, the basic royalty commences at a rate of one percent of gross revenues, rising to five percent in increments of one percent every eighteen production months. After payout, the royalty is the greater of thirty percent of net revenues and five percent of gross revenues. Payout will be deemed to have occurred when cumulative gross revenues first equal the sum of total eligible capital costs, operating costs, overhead allowances, royalties paid and the cumulative return allowance. Payout will be calculated on a working interest basis and, where there are many participants in a project, the payout points may vary for each participant. These Regulations were in effect December 12, 1991.

(d) Energy Monitoring Act, R.S.C. 1985, c. E-8

Energy Monitoring Regulations, amendment, SOR/91-570

These Regulations amend the Energy Monitoring Regulations, SOR/83-172 by making amendments to the Survey Questionnaire issued to industry by the Petroleum Monitoring Agency. Changes are made at least annually to the form of the Questionnaire to meet changing governmental and regulatory requirements. These Regulations were in effect October 3, 1991.

(e) Energy Supplies Emergency Act, R.S.C. 1985 (2nd Supp.), c. 19

Energy Supplies Allocation Board Exemption Order No. 13, SOR/91-56

This Regulation exempts the companies listed in the schedule to the Regulations from the Competition Act ${ }^{15}$ in respect of courses of action required of them by the Minister of Energy, Mines and Resources. The action the Minister may request is to develop or

is. R.S.C. 1985, c. C-34. 
carry out an implementation plan or arrangement in relation to the Energy Supplies Emergency Act. ${ }^{16}$ The exemption was requested by the companies listed because in order to carry out the actions requested of them by the Minister, they would be meeting with competitors in the petroleum and petroleum products market which could be interpreted as a contravention of the Competition Act. ${ }^{17}$ This Regulation was in effect December 24, 1990.

\section{Proposed Changes}

(a) Bill C-58, An Act to Amend the Oil and Gas Production and Conservation Act and Other Acts in Consequence Thereof, 3d Sess., 34th Parl., 1991-92

\section{Status: First Reading February 20, 1992}

The amendments contained in this Bill address the remaining recommendations of the Royal Commission on the Ocean Ranger Disaster. Some of the amendments are: the Minister of Energy, Mines and Resources will be able to override all other federal legislation in emergency situations where the safety of workers and operations are at risk; operators must obtain a certificate for any equipment or installation from a certifying authority (such authority to be prescribed by regulations currently being drafted) and the title of the Oil and Gas Production and Conservation Act ${ }^{18}$ will be changed to the Canada Oil and Gas Operations Act.

An Oil and Gas Administrative Advisory Council will be created to promote consistency and improvement in the administration of the regulatory regime. A board titled the Offshore Oil and Gas Training Standards Advisory Board will be established to enquire as to existing training standards and encourage the development and adoption of training standards for offshore oil and as operations.

(b) Bill C-13, Canadian Environmental Assessment Act, 3d Sess., 34th Parl., 1991-1992

Status: Formerly Bill C-78 in the previous session of Parliament, Second Reading in the Senate April 7, 1992

This Bill has been referred to the Standing Senate Committee on Energy, the Environment and Natural Resources. This legislation was discussed as Bill C-78 in last year's article. ${ }^{19}$

The Federal Environmental Assessment Review Office began in August, 1991 to seek comment on the list of projects likely to require a comprehensive study under Bill C-13. The comprehensive study is for projects likely to cause significant adverse environmental effects and the list would then become a regulation under the proposed Act. In the oil 
and gas category, projects likely to require a study include an oil refinery having an input capacity of more than 10,000 cubic metres per day; a sour gas processing facility with a sulphur output of more than 10,000 tonnes per day and a petroleum storage facility with a capacity in excess of 500,000 cubic metres.

(c) Offshore Pipeline Regulations (Proposed) - Canada Gazette Part I, Vol. 125, No. 16

These Regulations are proposed by the NEB under the National Energy Board Act ${ }^{20}$ and are an adaptation of the Onshore Pipeline Regulations. ${ }^{21}$ They define technical and documentation requirements and approval procedures to be followed for the design, construction, operation and abandonment of offshore pipelines under the NEB's jurisdiction. A draft of the Regulations was first sent out for comment in 1985 and then again in 1988.

(d) Canadian Oil and Gas Diving Regulations (Proposed) - Canada Gazette Part I, Vol. 126 , No. 14

These Regulations are proposed under the Oil and Gas Production and Conservation Act. $^{22}$ The Regulations specify minimum standards of training and practical experience for personnel directly engaged in diving operations relating to oil and gas operations on federally regulated lands.

\section{(e) Onshore Pipeline Regulations, SOR/89-303}

These Regulations will be amended to reflect the NEB's decision on the deliberations the NEB had with industry on the recommendations included in the NEB's report of June 1986 on an accident on Interprovincial Pipe Line Limited's system in February 1985. There will also be various housekeeping amendments. The proposed amendments are expected to be distributed for comment by the summer of 1992 .

\section{(f) National Energy Board Part VI Regulations, amendment (Proposed)}

The amendments to these Regulations were discussed in last year's article ${ }^{23}$ as a proposed change. Another draft of the proposed amendments was sent out for comment in August 1991.

\section{(g) Export and Import Reporting Regulations (Proposed)}

These proposed regulations would require companies exporting oil, natural gas or power, or importing natural gas to provide certain information to the NEB. These reporting requirements would be similar to those currently in the National Energy Board

$\begin{array}{ll}\text { 20. } & \text { Supra note } 13 . \\ 21 . & \text { SOR/89-303. } \\ \text { 22. } & \text { Supra note } 18 . \\ 23 . & \text { Supra note } 1 .\end{array}$


Part VI Regulations, ${ }^{24}$ but on the advice of the Standing Joint Committee on Regulatory Scrutiny, those reporting requirements will be removed and will form the new Export and Import Reporting Regulations. These regulations will be processed with the revisions to the Part VI Regulations. ${ }^{25}$

(h) Canada Oil and Gas Installations Regulations - Draft

These Regulations, as discussed in last year's article, ${ }^{26}$ are still in draft form.

(i) Canada Petroleum Resources Act, R.S.C. 1985, c. 36 (2d Supp.)

The Canadian Petroleum Association has been asked to comment on proposed changes to this Act, including the appeal procedures. The legislation is currently being redrafted. Jurisdiction over onshore areas will pass in the new legislation to the government of the Northwest Territories.

(j) Canada Oil and Gas Land Administration ("COGLA")

In April, 1991, COGLA staff were transferred to the NEB as part of the transfer of COGLA's regulatory responsibility for oil and gas activities on frontier lands.

\section{B. ALBERTA LEGISLATION}

\section{Statutes}

(a) Bill 44, Alberta Corporate Tax Amendment Act, 1991, 3d Sess., 22d Leg. Alta., 1991 (assented to June 25, 1991)

This Act makes numerous amendments to the Alberta Corporate Tax Act including the royalty tax credit for royalties payable after May 1984 and dispositions made after August 24, 1982. There is a new "royalty tax credit gas supplement" for corporations with tax years beginning or ending in 1991. For 1991 and subsequent tax years, sections 12.1 and 12.2, concerning royalty tax credits, of the Alberta Income Tax Act ${ }^{28}$ are repealed and a new Part II is added to the Alberta Corporate Tax Act ${ }^{29}$ for royalty credits and royalty credit gas supplements for individuals. This Act was in force June 25, 1991, except for amendments to section 1(2) which came into force as of January 1, 1991.

$\begin{array}{ll}\text { 24. } & \text { C.R.C., c. } 1056 . \\ \text { 25. } & \text { lbid. } \\ \text { 26. } & \text { Supra note 1. } \\ \text { 27. } & \text { R.S.A. 1980, c. A-17. } \\ \text { 28. } & \text { R.S.A. 1980, c. A-31. } \\ \text { 29. } & \text { Supra note } 27 .\end{array}$


(b) Arbitration Act, S.A. 1991, c. A-43.1

This Act repeals and replaces the Arbitration $\mathrm{Act}^{30}$ and moves section 17 of that Act, which dealt with gas price determination, to the Natural Gas Marketing Act, S.A. 1986, c. N-28. The Act will apply to agreements in which disputes are referred to arbitration unless the agreement specifically excludes such application. The arbitration tribunal will be composed of one arbitrator unless the agreement specifies otherwise. There are provisions for challenging the appointment of arbitrators, applying to the court to remove arbitrators and appointing substitute arbitrators. The tribunal may determine its own jurisdiction, procedures and any questions of law that arise and it may grant equitable remedies. An award is binding on the parties, unless subject to an appeal or there is an application to the court to set aside an award. A matter settled during an arbitration must be recorded in the form of an award. There is an appeal from an award if the agreement providing the arbitration procedure so states, or, on a question of law, if leave to appeal is granted by the court. This Act was in force September 1, 1991.

(c) Bill 5, Mines and Minerals Amendment Act, 1991, 3d Sess., 22d Leg. Alta., 1991 (assented to June 25, 1991)

Last year's article ${ }^{31}$ contained a discussion of this Act. In addition to other provisions, the Act provides that if an agreement issued pursuant to the Mines and Mineral $\mathrm{Act}^{32}$ contains a misdescription of a zone, the Minister may amend the agreement with the lessee's consent or cancel the agreement and provide compensation. This Act was in force June 25, 1991 except certain amendments which will come into force on proclamation.

(d) Bill 24, Municipal Taxation Amendment Act, 1991, 3d Sess., 22d Leg. Alta., 1991 (assented to June 25, 1991)

This Act allows municipalities to tax processing plants at a different rate than of other properties. A "processing plant" is defined as a plant for the extraction of gases, the refining or upgrading of oil or the production upgrading of other minerals. The lessee of a surface lease used for a processing plant is not assessed as being the owner of the lands.

\section{(e) Natural Gas Marketing Amendment Act, 1991 S.A. 1991, c. 25}

This legislation amends the Natural Gas Marketing Act $^{33}$ by adding a new section 9.1 concerning the continuation of netback pricing agreements. The Lieutenant Governor in Council may designate shippers as being subject to section 9.1 , and if a designated shipper is a party to a netback pricing agreement at the effective date of the order, the agreement continues to be binding on the parties until a date determined under the regulations 
pursuant to the Act, ${ }^{34}$ or the order is revoked. While the order is in effect, the designated shipper may not purchase gas for resale, except under a producer-shipper contract that was in effect on the effective date of the order. Section 9.1 will be repealed on November 1, 1994 unless sooner repealed. There is an accompanying change to the Natural Gas Marketing Regulation ${ }^{35}$ which is discussed later in this article. This legislation was proclaimed in force on July 4, 1991.

(f) Bill 6, Oil and Gas Conservation Amendment Act, 1991, 3d Sess., 22d Leg. Leg. Alta., 1991 (assented to June 15, 1991)

This legislation was discussed in last year's article ${ }^{36}$ as a proposed change. The amendments are to change the references to "production spacing units" to "drilling spacing units" and amend the provisions in the Oil and Gas Conservation Act $^{37}$ referring to those terms. There are definitions added for "experiment" and "experimental scheme" which are procedures for recovering or processing oil or gas using unproven methods and require the approval of the Energy Resources Conservation Board ("ERCB"). This legislation was in force June 25, 1991 except the amendment to the Mines and Minerals Act ${ }^{38}$ which will come into force on proclamation.

\section{(g) Safety Codes Act, S.A. 1991, c. S-0.5}

This Act repeals seven Acts including the Boilers and Pressure Vessels Act. ${ }^{39}$ There was a brief discussion of this legislation as a proposed change in last year's article. ${ }^{40}$ The Act establishes the Safety Codes Council and provides that the Minister may appoint Administrators who in turn appoint safety code officers, formerly known as inspectors under the repealed legislation.

The safety code officers have the authority, without warrant, to enter premises to inspect and ensure compliance with the Act, they may remove evidence and demand production of documents and, in an emergency, take any action they consider necessary to reduce or remove the danger. In short, the safety code officers and the Administrators have extensive powers to ensure compliance with the Act. This Act is in force on proclamation but was not proclaimed as of May 15, 1992.

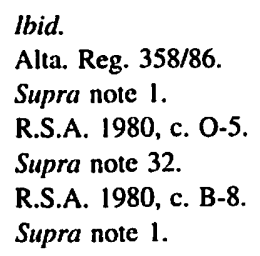


(h) Bill 7, Turner Valley Unit Operations Amendment Act, 1991, 3d Sess., 22d Leg. Alta., 1991 (assented to June 25, 1991)

This legislation amends the Turner Valley Unit Operations Act ${ }^{41}$ by allowing for the ERCB to amend an operation order for the Turner Valley Unit on its own motion or on the motion of an interested party.

\section{(i) Other Statutes}

The following updates were statutes discussed as proposed changes in last year's article: ${ }^{42}$

Natural Resources Conservation Board Act, S.A. 1990, c N.-5.5 - proclaimed in force June 3, 1991.

Bill 21, Rural Utilities Amendment Act, 1991, 3d Sess., 22d Leg. Alta., 1991 - in force July 1, 1991 except amendments to sections $36(6.1)$ and 49.1 which came into force on June 25, 1991.

Bill 23, Environmental Council Amendment Act, 1991, 3d Sess., 22d Leg. Alta., 1991 died on the order paper.

2. Regulations

The Regulations are described under the name of the Act they are made pursuant to.

(a) Alberta Corporate Tax Act, R.S.A. 1980, c. A-17

\section{Alberta Corporate Tax Amendment Regulation, Alta. Reg. 291/91}

This Regulation amends the Alberta Corporate Tax Regulation ${ }^{43}$ by amending the provisions relating to the calculation of the period, average par price and the specified rate to be used in calculating the Royalty Tax Credit and Royalty Credit and Supplements under the Alberta Corporate Tax Act. ${ }^{44}$ It was filed September 5, 1991.

(b) Metis Settlements Act, S.A. 1990, c. M-14.3

Metis Settlements Land Registry Regulation, Alta. Reg. 361/91

This Regulation establishes the Metis Settlements Land Registry. The purpose of the Registry is to record ownership of all patented land that is land held in fee simple by the Metis Settlements General Council and to handle registration of all transactions affecting 
such lands. There are provisions for compensation for persons sustaining loss through entries in registers not authorized by this Regulation. The Regulation also contains the administrative guidelines for the Registry. It was filed November 1, 1991.

Land Interests Conversion Regulation, Alta. Reg. 362/91

This Regulation covers the process for conversion of a certificate of occupancy under the former Act to a Metis title for the purpose of the Metis Settlements Act. ${ }^{45}$ It was filed November 1, 1991.

Metis Settlements Subdivision Regulation, Alta. Reg. 363/91

This Regulation contains the provisions governing the subdivision of any land described in a Metis title register or any allotments or leasehold established under the Metis Settlements Land Registry Regulation. ${ }^{46}$ It was filed November 1, 1991.

(c) Mines and Minerals Act, R.S.A. 1980, c. M-15

Compensatory Royalty Amendment Regulation, Alta. Reg. 379/91

This Regulation amends the Compensatory Royalty Regulation ${ }^{47}$ by changing the calculation of the value of the Crown's royalty share of natural gas for a month. The amended provision is that the value of the Crown's royalty share shall be $80 \%$ of the Alberta average market price prescribed by the Minister pursuant to the Natural Gas Royalty Regulation ${ }^{48}$ for that month, with no deductions for gathering, compressing or processing. This Regulation was filed November 22, 1991.

Experimental Project Petroleum Royalty Regulation, Alta. Reg. 65/92

This Regulation repeals the Experimental Project Petroleum Royalty Regulation. ${ }^{49}$ The provisions have been expanded, particularly the definition of "experimental oil," to include experiments that do not necessarily involve secondary and tertiary oil recovery. The concept of a royalty period is introduced; the Minister may now specify a royalty period for a specific scheme approved by the ERCB. This Regulation was filed February $13,1992$. 
Exploration Amendment Regulation, Alta. Reg. 287/91

This Regulation amends the Exploration Regulation. ${ }^{50}$ There are numerous minor amendments. It was filed August 29, 1991.

Horizontal Well Petroleum Royalty Amendment Regulation, Alta. Reg. 405/91

The Horizontal Well Petroleum Royalty Regulation ${ }^{\text {s1 }}$ is amended by the addition of provisions for "qualifying oil sands" which are oil sands recovered through a horizontal extension approved by the Minister. It also provides that the Oil Sands Royalty Regulation, $1984^{52}$ does not apply to "qualifying oil sands."

This Regulation results in royalty reduction for horizontal wells. Horizontal wells drilled during 1991 and 1992 will be eligible to receive a royalty adjustment for 24 production months. This adjustment must be taken after March 1, 1991 and before January 1, 1997. This Regulation was filed December 12, 1991.

\section{Oil Royalty Regulation, Alta. Reg. 403/91}

This Regulation provides incentives for additional production of crude oil and oil sands from new drilling activity. There is a development holiday for crude oil and oil sands wells drilled or deepened during the qualifying period, with certain exceptions. To be eligible a well must be an oil well or an oil sands well and be spudded or deepened after October 31, 1991 but before April, 11993.

The exploration oil holiday is available to crude oil wells drilled or deepened during the qualifying period, the same period for spudding or deepening applies as for the development holiday.

Generally, wells qualifying under other incentive programs or subject to a commercial oil sands agreement will not be eligible under this Regulation. It was filed December 12, 1991.

Oils Sands Regulation, Alta. Reg. 228/91

This Regulation repeals the Oil Sands Regulation, $1978 .^{53}$ It puts in place new regulations governing oil sands agreements and existing and new oil sands leases. Lessees who hold second term oil sands leases must either produce oil sands from their leases at the capacity prescribed by their lease or submit, for approval, a development plan for the lease which commits to the production of oil sands before the end of the third term of the lease. All renewal terms for oil sands leases will now be 15 years. This regulation was filed June 27, 1991. 


\section{Petroleum Royalty Amendment Regulation, Alta. Reg. 406/91}

This Regulation amends the Petroleum Royalty Regulation ${ }^{54}$ by adding a definition for "deepening" and "deepening interval" in reference to an oil well and expanding the provisions concerning when crude oil is considered new oil. Shut-in zones classified as old oil will now be permitted to convert to new oil status as outlined in the Regulation. It also removes "production" and "production spacing unit" and substitutes "drilling" and "drilling spacing unit" where those terms appear. This Regulation was filed December $12,1991$.

\section{Petroleum Royalty Amendment Regulation, Alta. Reg. 66/92}

This Regulation amends the Petroleum Royalty Regulation ${ }^{55}$ by adding a new section 11.1 to provide royalty relief for an enhanced recovery scheme as referred to in section 11 of the Regulation. ${ }^{56}$ It was filed February 13, 1992.

\section{Reactivated Well Incentive Regulation, Alta. Reg. 404/91}

This Regulation describes the royalty exemption for a "reactivated well." This is a well that is an oil or oil sands well that has a finished drilling date earlier than September 1, 1990 from which production was not obtained between August 31, 1990 and November 1, 1991 and from which eligible oil is obtained before April 1, 1993. It does not include an "ineligible well" as defined in the Regulation. All eligible production will be exempted from royalty that would otherwise be payable under the Petroleum Royalty Regulation ${ }^{57}$ and the Oil Sands Royalty Regulation, 1984. ${ }^{58}$ This Regulation was filed December 12, 1991.

(d) Natural Gas Marketing Act, S.. 1986, c. N-2.8

Natural Gas Marketing Amendment Regulation, Alta. Reg. 263/91

This Regulation amends the Natural Gas Marketing Regulation ${ }^{59}$ by adding a new section 14.2 which describes the procedure by which a designated shipper or one or more of its netback producers may file with the Alberta Petroleum Marketing Commission a notice of intention to petition the Minister to have a vote of the shipper's netback producers. The question of the vote being whether the application of section 9.1 of the Natural Gas Marketing Act ${ }^{60}$ to the shipper and the netback pricing agreements to which the shipper is a party, should be terminated.

$\begin{array}{ll}\text { s4. } & \text { Alta. Reg. } 248 / 90 . \\ \text { 55. } & \text { Ibid. } \\ \text { s6. } & \text { Ibid. } \\ \text { 57. } & \text { Ibid. } \\ \text { s8. } & \text { Supra note } 52 . \\ \text { 59. } & \text { Supra note } 35 . \\ \text { 60. } & \text { Supra note } 33 .\end{array}$


(e) Natural Resources Conservation Board Act, S.A. 1990, c. N-5.5

Funding For Eligible Interveners Regulation, Alta. Reg. 278/91

This Regulation sets forth the guidelines by which an intervener in an application before the Natural Resources Conservation Board ("NRCB") who claims to be an eligible intervener, may make a claim for an award of costs related to preparation and presentation of the intervener's submission. An eligible intervener is an intervener the NRCB considers to be directly affected by a reviewable project. The Regulation describes the basis on which an application for an award of costs is to be made and the basis on which the NRCB may award or deny the intervener's claim. There are also provisions whereby the intervener may request advance funding of those costs. This Regulation was filed August 9, 1991.

Rules of Practice of the Natural Resources Conservation Board, Alta. Reg. 345/91

As the title describes, this Regulation contains the Rules of Practice required before the NRCB. It was filed October 18, 1991.

(f) NOVA Corporation of Alberta Act, R.S.A. 1990, c. N-12

NOVA Terms of Service Regulation, Alta. Reg. 67/92

This Regulation provides that NOVA may deliver gas during any day, under agreements by which it provides interruptible service to a customer at a designated delivery point, only to the extent that the volumes to be delivered during a day is not greater than the amount by which the maximum daily delivery capacity applicable to that delivery point and that day exceeds the contracted firm capacity for that delivery point for that day. The Minister may designate the delivery point on NOVA's system to which this Regulation applies.

This Regulation is a result of concern that the availability of interruptible delivery service at the Alberta/British Columbia border point was being used to dictate upstream suppliers' access on ex-Alberta delivery capacity without regard for any of the firm transportation contracts existing for the NOVA System. ${ }^{61}$ On June 30, 1994, this Regulation will be repealed. It was filed February 13, 1992.

Alta. Reg. 79/92 (Ministerial Order 3/92)

This Regulation designates the point on NOVA's pipeline system described in the NOVA Tariff as Alberta-British Columbia Border No. 2001, being the Alberta/B.C. delivery point in the Crow's Nest Pass, as the point to which the NOVA Terms of Service Regulation $^{62}$ applies. It was in force March 1, 1992. 
(g) Oil and Gas Conservation Act, R.S.A. 1980, c. O-5

Oil and Gas Conservation Amendment Regulation, Alta. Reg. 374/91

This Regulation amends the Oil and Gas Conservation Regulations ${ }^{63}$ by revising Part 4 of the Regulations concerning drilling spacing units and target areas. The amendment outlines what an applicant must show when requesting a drilling spacing unit of smaller than normal size, the guidelines for calculating penalties for off-target wells in a special drilling spacing unit and guidelines for calculating penalty factors for wells in corner target areas. It was filed November 19, 1991.

(h) Take-or-pay Costs Sharing Act, S.A. 1986, c. T-0.1

Take-or-pay Costs Sharing Amendment Regulation, Alta. Reg. 407/91

This Regulation amends the Take-or-pay Costs Sharing Regulation ${ }^{64}$ by exempting gas from levies under the Regulation in a delivery month if that gas is delivered to the TransCanada Piplines Limited ("TCPL") system or an extra-provincial system, and the Alberta Petroleum Marketing Commission recognizes that gas as being delivered to fulfil contractual obligations relating to the transportation and sale of gas produced outside Alberta. It was filed on December 12, 1991 but is effective as of November 1, 1990.

\section{Proposed Changes}

(a) Bill 9, NOVA Terms of Service Regulation Validation Act, 4th Sess., 22d Leg. Alta., 1991

This proposed Act would validate the NOVA Terms of Service Regulation. ${ }^{65}$ The regulation making powers under the NOVA Corporation of Alberta Act $t^{66}$ are limited; therefore, the Regulation requires validation by legislation. It also provides that no action may be brought against NOVA Corporation of Alberta or any of its employees, agents or directors in respect of anything done in pursuance of the NOVA Terms of Service Regulation. $^{67}$ It received Royal Assent on May 15, 1992.

(b) Bill 10, Energy Resources Conservation Amendment Act, 1992, 4th Sess., 22d Leg. Alta., 1992 - Status: In Committee April 10, 1992

This Bill would amend sections 23 and 34 of the Energy Resources Conservation Act. ${ }^{68}$ The amendments expand the ERCB's powers and provides it with greater flexibility to conduct co-operative proceedings or enter into arrangements with the federal

$\begin{array}{ll}\text { 63. } & \text { Alta. Reg. } 151 / 71 . \\ 64 & \text { Alta. Reg. } 366 / 86 . \\ 65 . & \text { Alta. Reg. } 67 / 92 . \\ 66 . & \text { R.S.A. 1980, c. N-12. } \\ \text { 67. } & \text { Supra note } 65 . \\ 68 . & \text { R.S.A. 1980, c. E-11. }\end{array}$


government or any provincial government or any of their agencies. In addition, the ERCB would be able to hold joint hearings with other agencies in respect of projects that may cross provincial or international borders. The ERCB would be allowed to enforce its orders through the courts.

(c) Bill 11, Petroleum Marketing Amendment Act, 1992, 4th Sess., 22d Leg. Alta., 1992 - Status: In Committee April 10, 1992

This Bill would amend the Petroleum Marketing $A c t^{69}$ by revising the provisions relating to the powers of the Alberta Petroleum Marketing Commission and expanding the provisions relating to regulations that may be made.

(d) Bill 12, Natural Gas Marketing Amendment Act, 1991 4th Sess., 22d Leg. Alta., 1992 - Status: In Committee April 20, 1992

This Bill would amend the Natural Gas Marketing $A c t^{70}$ by allowing for additional contracted services to be provided by the Alberta Petroleum Marketing Commission on behalf of buyers or sellers under a gas contract. Also, section 9 of the $\mathrm{Act}^{71}$ is repealed and a new section relating to a Commission finding of producer support is substituted for it. Netback agreements may be extended to November 1, 1994.

The amendments require shippers of netback gas to obtain the support of producers for the quantity and price at which the shipper resells the producer's gas. Also, producers would be able to vote on the terms and conditions of a downstream contract, in addition to price and quantity.

(e) Bill 18, Mines and Minerals Amendment Act, 1992, 4th Sess., 22d Leg. Alta., 1992 - Status: First Reading April 15, 1992

This Bill makes numerous amendments to the Mines and Minerals $A c t^{72}$ including amendments to the provisions for the Minister's action in respect of agreements that may artificially or unduly reduce royalties and the provisions for recalculation of royalty.

(f) Bill 23, Environmental Protection and Enhancement Act, 4th Sess., 22d Leg. Alta., 1992 - Status: First Reading May 13, 1992

This proposed Act which had died on the order paper at the end of the prior session has been reintroduced. It incorporates nine existing Acts including Clean Air Act, ${ }^{73}$ Clean Water Act ${ }^{74}$ and Land Surface Conversation and Reclamation Act. ${ }^{75}$

\author{
R.S.A. 1980, c. P-5. \\ Supra note 33. \\ Ibid. \\ Supra note 32. \\ R.S.A. 1980 , c. C- 12 . \\ R.S.A. 1980 , c. C-13. \\ R.S.A. 1980 , c. L-3.
}


(g) Gas Royalty Simplification Project

This project is continuing to be worked by industry and government. Deloitte \& Touche released their report as discussed in last year's article ${ }^{76}$ but both industry and government agreed there needed to be more fundamental changes to the royalty reporting process for Crown natural gas royalties. Industry and government met in November 1991 to discuss moving this project ahead and agreed to work towards preparing a joint recommendation for June 1992.

\section{BRITISH COLUMBIA LEGISLATION}

\section{Statutes}

(a) Land Titles Amendment Act, 1991, S.B.C. 1991, c. 12

This Act amends the Land Titles Act ${ }^{77}$ by providing for a standard form of instrument for use in all land dealings other than transfers or mortgages. It was in force May 1, 1992.

2. Regulations

The Regulations are described under the name of the Act they are issued pursuant to.

(a) Land Title Act, R.S.B.C. 1979, c. 219

B.C. Reg. $33 / 92$

This Regulation brought into force the Land Title Amendment Act, $1991^{78}$ and amends the Land Title (Transfer Forms) Regulation ${ }^{79}$ by adding provisions for the transfer form of general instruments as contemplated by the Land Title Amendment Act, $1991 .^{80}$ It was effective May 1, 1992.

(b) Petroleum and Natural Gas Act, R.S.B.C. 1979, c. 323

\section{B.C. $\operatorname{Reg} 216 / 91$}

This Regulation amends the Petroleum and Natural Gas Drilling Licence Regulation ${ }^{81}$ by adding a provision that a licensee may terminate a portion of its drilling licence if application is made for a lease and the portion is included in a unitization agreement. The

Supra note 1.

R.S.B.C. 1979, c. 219.

S.B.C. 1991, c. 12.

B.C. Reg. 533/90.

so. Supra note 78.

8I. B.C. Reg. 10/82. 
lease so issued must only include a zone if that zone is specified as a unitized zone in the unit agreement. This Regulation was approved July 5, 1991.

\section{Drilling and Production Regulation, B.C. Reg. 336/91}

This Regulation repeals the Drilling Production Regulation ${ }^{82}$ and replaces it with the provisions of this Regulation which govern drilling and production of oil and gas in British Columbia. This is a complete rework of the prior Regulation. ${ }^{83}$ Approved December 20, 1991.

\section{B.C. Reg. $62 / 92$}

This Regulation amends the Petroleum and Natural Gas Drilling Licence Regulation ${ }^{84}$ by adding provisions allowing an extension to the term of a drilling licence if drilling of a well has been delayed due to completion of an environmental or socioeconomic study, a public hearing or an investigation. It was approved March 12, 1992.

(c) Pipeline Act, R.S.B.C. 1979, c. 328

\section{B.C. Reg. $28 / 91$}

This Regulation amends the Pipeline Regulations ${ }^{85}$ by adding a provision requiring a company to notify the Ministry of any gas or oil spill, damage to a pipeline or incidents likely to contribute to or cause a spillage. Ordered effective January 22, 1991.

\section{B.C. Reg. $66 / 92$}

This Regulation amends the Pipeline Regulations ${ }^{86}$ by repealing section 8 and adding a new section 8 concerning the provisions applying to the crossing of a pipeline by a highway, utility line or other pipeline. Ordered effective March 11, 1992.

(d) Waste Management Act, S.B.C. 1982 c. 41

\section{Gasoline Vapour Pressure Regulation, B.C. Reg. 63/92}

This Regulation provides that anyone who refines gasoline within British Columbia must ensure that gasoline leaving their refinery, that is intended for use in motor vehicles, must meet the Reid Vapour Pressure for the month and area as established by the Regulation. The Regulation also describes how the Reid Vapour Pressure is to be determined. It was approved March 12, 1992.

$\begin{array}{ll}\text { 82. } & \text { B.C. Reg. } 628 / 76 . \\ \text { 8.. } & \text { Ibid. } \\ \text { s. } & \text { Supra note } 81 . \\ \text { 8s. } & \text { B.C. Reg. } 451 / 59 . \\ \text { x6. } & \text { Ibid. }\end{array}$




\section{Return of Used Lubricating Oil Regulation, B.C. Reg. 64/92}

This Regulation provides that every seller (whether it is a service station or the corner store) of lubricating oil, being engine transmission fluid and gear oil, must provide a return facility to accept used lubricating oil from its customers without charge. Contravention of this Regulation is an offence liable to a $\$ 5,000$ fine. This Regulation was approved March 12, 1992.

\section{Proposed Changes}

(a) Bill 18, Energy Council Act, 1st Sess., 35th Parl. B.C., 1992

Status: First Reading April 21, 1992

This Act would establish the British Columbia Energy Council whose purpose would be to advise the Minister on energy matters.

(b) Bill 27, Mineral Land Tax Amendment Act, 1992, 1st Sess., 35th Parl. B.C., 1992 Status: First Reading April 24, 1992

This Act would amend provisions under the Mineral Land Tax Act, ${ }^{87}$ the Mineral Tax $A c t^{88}$ and the Petroleum and Natural Gas Act ${ }^{89}$ concerning the rate of acreage tax on the ownership of mineral lands. It also repeals the establishment of the Mineral Tax Review Board under the Mineral Land Tax Act ${ }^{90}$ and re-establishes the Board under the Mineral Tax Act. ${ }^{91}$

(c) There were three Member's Bills discussed in last year's article:92 Bill M203, Spill Prevention and Reporting Act, ${ }^{93}$ Bill M206, An Act to Enforce Pollution Offences and Create An Environmental Protection Fund ${ }^{94}$ and Bill M209, Environmental Protection Act. ${ }^{95}$ None of these bills progressed beyond 1st Reading before completion of the 4th Session of the 34th Parliament of the B.C. Legislature.

(d) The British Columbia government released a document titled "Environment 2001" in November 1991 which describes the government's goals in terms of pollution and the environment. One of the commitments is to introduce a new Environmental Protection Act but as of April 28, 1992 that legislation had not been introduced.

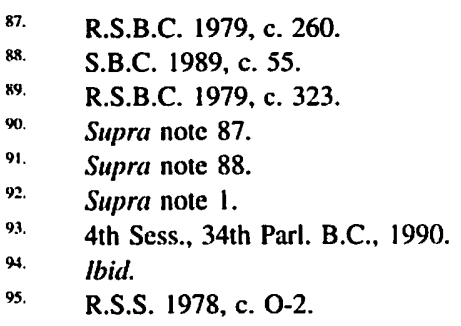




\section{SASKATCHEWAN LEGISLATION}

\section{Statutes}

(a) The Oil and Gas Conservation Amendment Act, 1991, S.S. 1990-91, c. 39

This Act establishes the Oil and Gas Conservation Board. The Minister, on his own motion or on the application of an interested person, may refer any matter arising pursuant to The Oil and Gas Conservation Act, ${ }^{96}$ or any order or regulation made pursuant to it, to the Board for an investigation, hearing or inquiry. The Regulation describes the powers of and guidelines for proceedings of the Board.

The Act also establishes the Oil and Gas Revolving Fund which is to be used by the Minister to pay expenses incurred to carry out the Minister's functions under The Oil and Gas Conservation $\mathrm{Act}^{97}$ and other statutes related to oil and gas. A portion of the monies for the Fund are to come from prescribed fees to be paid by holders of licences or unit operators. There are also numerous other amendments. Assented to June 18, 1991 , in force on assent.

\section{Regulations}

The Regulations are described under the name of the Act they are made pursuant to.

(a) The Crown Minerals Act, S.S. 1984-85-86, c. C-50.2

The Petroleum and Natural Gas Amendment Regulations, 1991 (No. 3), Sask. Reg. $58 / 91$

This Regulation amends The Petroleum and Natural Gas Regulations, $1969^{98}$ by adding Parts VII, VIII and IX which establish a registry system for transfer documents, security notices and other documents relating to permits, drilling reservations, leases or other Crown dispositions and the holders of them. The Regulation describes what may be registered and the process for registration. It was filed July 19, 1991.

The Petroleum and Natural Gas Amendment Regulations, 1991 (No. 5), Sask. Reg. $81 / 91$

This Regulation amends The Petroleum and Natural Gas Regulations, $1969^{99}$ by adding provisions for Crown royalties for horizontal incentive oil. This is new oil that is the portion of the first 12,000 cubic metres of oil produced from a non-deep horizontal oil well drilled after April 1, 1991, that is not otherwise qualified under the Regulation

$\begin{array}{ll}\text { 9. } & \text { R.S.S. 1978, c. O-2. } \\ \text { 97. } & \text { Ibid. } \\ \text { 98. } & \text { Sask. Reg. } 8 / 69 . \\ 99 . & \text { Ibid. }\end{array}$


or is produced after April 1, 1991. This Regulation was deemed to have been in force from February 1, 1991.

The Petroleum and Natural Gas Amendment Regulations, 1992, Sask. Reg. 3/92

This Regulation amends The Petroleum and Natural Gas Regulations, $1969^{100}$ by adding a provision allowing the Minister to waive certain requirements of the Regulations where, in the Minister's opinion, exploration or development of permit lands in "The Great Sand Hills" area has been or will be delayed by environmental restrictions. The provisions for advertisement of a Crown sale of oil and gas rights are also amended. This Regulation was filed January 29, 1992.

(b) The Freehold Oil and Gas Production Tax Act, S.S. 1982-83, c. F-22.1

The Freehold Oil and Gas Production Tax Amendment Regulations, 1991 (No. 3), Sask. Reg. 80/91

The Freehold Oil and Gas Production Tax Regulations, $1983^{101}$ are amended by adding tax provisions for horizontal incentive freehold oil, being horizontal incentive oil produced from freehold lands. These Regulations were deemed in force from February $1,1991$.

(c) The Oil and Gas Conservation Act, R.S.S. 1978, c. O-2

The Oil and Gas Conservation Amendment Regulations, 1991, Sask. Reg. 29/91

These Regulations amend The Oil and Gas Conservation Regulations, $19855^{102}$ There are numerous amendments including the addition of provisions for horizontal wells in heavy oil areas, amendment of the provisions for gas conservation and gas well tests, disposal of saltwater and amendment of various definitions. They are deemed to have been in force from July $1,1991$.

The Oil and Gas Revolving Fund Regulations, R.S.S., c. 0-2, Reg. 4

These Regulations prescribe the expenses that may be paid out of the Oil and Gas Revolving Fund, established by The Oil and Gas Conservation Amendment Act, $1991 .{ }^{103}$ It also prescribes the well fees which will raise the approximately fifty per cent of the amount of the Revolving Fund to be borne by the oil and gas industry, the other fifty per cent is the responsibility of the Saskatchewan Department of Energy and Mines.

100. Ibid.

101. Sask. Reg. 11/83.

102. R.R.S., c. O-2, Reg. 1.

103. S.S. 1990-91, c. 39. 
The fee schedule will remain constant and adjustment factors will be applied to those fees to determine the levy for each year. These Regulations were deemed to be in force from April 1, 1991.

\title{
II. REGULATORY DEVELOPMENTS
}

\section{A. FEDERAL}

1. National Energy Board

On September 3, 1991 the NEB opened its offices in Calgary at:

\author{
311 - 6th Avenue S.W. Calgary, Alberta \\ T2P $3 \mathrm{H} 2$
}

General Inquiries: (403) 292-4800

(a) Decisions

(i) RH-1-91 TransCanada Pipelines Limited - Toll Application

After releasing an interim decision on August 2, 1991 for tolls effective July 1, 1991 and the decisions portion only on October 4, 1991, the NEB released reasons for decision dated September 1991 on December 30, 1991.

TCPL had requested a 19.6 percent increase over the 1990 tolls and an increase in the rate of return on common equity from 13.25 percent to 14.50 percent. The NEB approved an average toll for 1991 was 16.0 percent higher than in 1990 with a rate of return on common equity of 13.50 percent.

One of the more contentious issues addressed at the hearing was TCPL's request for recovery of the balance in the Corporate Relocation deferral account in the 1991 revenue requirement. The NEB decided that a greater portion of the relocation costs should be borne by the shareholders, that the balance of the deferral account eligible for carrying charges should be reduce to reflect the income tax saving available to TCPL by incurring these costs and that the recovery of the approved amount should be amortized over two years.

This was the first time that TCPL attempted to incorporate the Task Force process into the preparation of a tolls application. The NEB stated: ${ }^{104}$

The Board recognizes that this process is its infancy in proceedings before the Board and is encouraged by the initial efforts of interested parties to develop a pre-hearing settlement process. The Board expects that, if interested parties find it beneficial and cost effective, this process will continue to evolve as a means of streamlining proceedings before the Board. 


\section{(ii) RH-4-91 TransCanada Pipelines Limited - 1992 Toll Application}

On April 30, 1992 the NEB released its reasons for decision dated March, 1992.

As in its previous application for 1991 tolls ${ }^{105}$ TCPL convened a Joint Industry Task Force, membership of which was open to the public, which was composed of various shippers, producers, industry associations, distributors, provincial government representatives and other interested parties. Because more extensive use was made of the Task-Force to resolve issues prior to the hearing and many issues were deferred to the next TCPL toll proceeding, the hearing lasted only four days.

The NEB approved a rate of return on common equity of 13.25 percent that was the result of a negotiated settlement between certain Task Force participants.

The position of the NEB relating to Task Force settlements was stated by R. Byron Horner, a member of the NEB: ${ }^{106}$

The Board's current position with respect to negotiated settlements and task forces in general, remains the same as stated in the Board's 1988 report entitled Improving the Regulatory Process. In that report the Board said it does not believe that the National Energy Board Act precludes the acceptance of negotiated settlements as a means of setting just and reasonable tolls. The Board also said it was prepared to consider negotiated settlements if the settlement process satisfactorily addresses the following five concerns:

1. Parties affected by a settlement should have a fair opportunity to participate and have their interests recognized and appropriately weighed;

2. A negotiated settlement process should not fetter the Board's ability and discretion to take into account the full public interest which often extends beyond the immediate concerns of the negotiating parties;

3. The settlement process must produce adequate information on the public record for the Board to satisfy itself that negotiated settlement would result in tolls which are just and reasonable;

4. The Board's role as an independent adjudicator must not be impinged by being a party to the negotiations;

5. The Board cannot accept "package deal" negotiated settlements consisting of various elements, not all of which might, in the Board's judgment, result in tolls which are just and reasonable.

106. R.B. Horner, "The National Energy Board Agenda" (Address to U.S./Canada Crossborder Natural Gas Regulation Conference, 17 January 1992). 
Mr. Horner stressed that the NEB must find tolls to be "just and reasonable" so it must see at least some of the evidence and the NEB cannot abdicate its responsibility in favour of a Task Force unless the National Energy Board $\mathrm{Act}^{107}$ is changed.

However, acceptance by the NEB of the settlements negotiated by the Task Force indicates a positive response to the Task Force process.

(iii) EH-3-89 Hydro Quebec, Le Procureur general du Quebec and the Grand Council of the Crees (of Quebec)

The NEB decision to place a condition on the licenses issued to export electricity to the New York Power Authority and Vermont Joint Owners was appealed to the Federal Court of Appeal. The condition was that the licenses will remain valid only if any required production facilities, for which construction had not been authorized at the completion of the hearing, will be subjected, prior to construction, to the applicable federal environmental assessment and review procedures.

The appeals by Le Procureur general and Hydro Quebec regarding the jurisdiction of the NEB were allowed, and the Court found that the NEB exceeded its authority in imposing the condition. ${ }^{108}$

Marceau J.A. states at page 221:

...the Board's jurisdiction still is and has always been the granting of leave to export electricity. The factors which may be relevant in considering an application for leave to export electricity and the conditions which the Board may place on its leave clearly cannot relate to anything but the export of electricity.

Further, at page 222:

It seems clear that, as it is understood in the Act (The National Energy Board Act, Section 2) with respect to electricity, export does not cover production itself, and it is only reasonable that this should be so. Of course, anyone wishing to export a good must produce or arrange for it to be produced elsewhere, but when he produces it or arranges for its production elsewhere he is not exporting it, and when he is exporting it, he is not producing it.

It is clear that the construction of electric energy production facilities raises serious environmental questions which must be considered and resolved, but these questions are the responsibility of other authorities besides the Board, and those authorities have no need of the Board's support in order to act, nor in any case is it the Board's function to lend such support.

108. Quebec (Procureur general) v. Office nationale de L'energie, [1991] 132 N.R. 214. 
This decision has resulted in NEB environmental reviews of electricity export applications becoming more of a matter of form, since the NEB cannot review the environmental impact of producing the electricity which the applicant proposes to export.

\section{(iv) GH-1-91 TransCanada Pipelines Limited - Blackhorse Extension}

In Reasons for Decision dated July 1991, the NEB denied an application by TCPL to build the Blackhorse extension pipeline in southwestern Ontario. The proposed extension would link the existing Niagara Line and the Empire State Project and would accommodate new gas exports.

The NEB conducted an environmental screening of TCPL's application which determined that the potentially adverse environmental effects, and any directly related social effects associated with the applied-for facilities, would be insignificant or mitigable with known technology. After conducting the public hearing and assessing the proposal, the NEB found, however, that a viable alternative means of accessing the targeted markets existed by expanding TCPL's Niagara Line which would result in minimal environmental impact. The NEB decided that there was clear evidence that the markets proposed to be served by the Blackhorse Extension could be served by less expensive and environmentally superior means through expansion of the existing Niagara Line and that the facilities, consequently, were not required, so denied TCPL's application.

In the meantime, the U.S. Federal Energy Regulatory Commission ("FERC") rendered its decision on the competing applications for Niagara facilities on the U.S. side approving the Empire State project and denying alternatives proposed by Tennessee Gas Pipeline and CNG Transmission. The Empire State approval was conditional upon the NEB approval of the Blackhorse Extension.

On August 2, 1991 TCPL, ANR Pipeline Company, Rochester Gas \& Electric Corporation and St. Clair Pipelines Limited applied for a review of the NEB's decision. The NEB decided that the recent decision of the FERC constituted a changed circumstance which raised doubt as to the correctness of the NEB's decision and justified proceeding with a review, which would be conducted on an expedited basis.

In October 1991 the Federal Court Trial Division upheld the application of Transmission Corporation ("CNG") to discontinue the NEB's review on the grounds that CNG had had no opportunity to comment on the need for a review before the decision to hold one was made. The court further ordered that Messrs. Priddle and Frechette refrain from participating in any further reviews on the grounds that they may have been prejudiced as a result of meeting with some of the participants.

After asking for comments from interested parties, the NEB announced a public hearing beginning May 11, 1992 to review the 1991 reasons for the decision that denied the 
application of TCPL to construct the Blackhorse Extension. ${ }^{109}$ The NEB proposes to hear all evidence and all argument on all issues before making a decision on any one issue. CNG had argued that until the NEB had determined if the decision in GH-1-91 was correct, it had no jurisdiction to consider TCPL's facilities application for the Blackhorse Extension.

\section{(v) GHW-2-91 Alberta Natural Gas Company Ltd. - System Expansion}

On May 21, 1992, the NEB released its decision dated May 1992 approving an application by Alberta Natural Gas Company Ltd. ("ANG") to expand its pipeline system in Southern British Columbia to serve markets in northern California and the Pacific Northwest.

The facilities consist of additions and modifications to three compressor stations which, together with the pipeline looping planned by Foothills Pipe Lines (South B.C.) Ltd., will increase the export capacity to accommodate gas deliveries through the Pacific Gas Transmission ("PGT") expansion.

The decision is of interest because, although the NEB states that it took into account the overall supply and market information filed in support of the application, approval was given based on 30 year signed unconditional firm service transportation contracts for the entire expansion volume, and before PGT has obtained the necessary gas export licenses from the NEB. Interveners had requested that ANG should bear the risk of unpaid demand charges, rather than passing them on to the remaining shippers, but the NEB declined to make such a requirement. Because of the competing pipeline applications between PGT and Altamont, shippers felt that the entire expansion volume may not, in the end, be shipped through these facilities and unpaid demand charges would result.

(b) Evolving Matters

\section{(i) GHW-1-91 Proposed Changes to the Application of the Market-Based Procedure}

On August 21, 1991, the NEB announced a number of proposed changes to the way it applies the Market Based Procedure, the procedure by which the NEB assesses applications for licenses to export natural gas. The Market-Based Procedure consists of three parts: an Export Impact Assessment, a Complaints Procedure and Other Public Interest Considerations. The proposed changes affect the last two components, and the intent is to streamline the hearing process by ensuring that only those issues relating to the public interest will be addressed in public hearings.

In place of the former public interest considerations, namely gas supply, markets and transportation, and sales contract arrangements, the NEB proposed the following: 
1. verification that there is producer support for gas export licence applications;

2. verification that there are provisions in the export sales contracts for payment of the associated transportation charges on Canadian pipelines over the term of the export sales contract; and

3. an assessment of the appropriate length of the term for an export contract having regard to:

i) evidence on the adequacy of the gas supplies available to the export licence applicant to support the applied for volumes over the requested licence term;

ii) evidence on the necessity of the requested term in light of the terms of the associated gas sales and transportation contracts and terms of the approvals from other regulatory bodies; and

iii) any other evidence which the Board deems to be relevant to the appropriate term of licence.

It is of interest that the Alberta government, in its response, while agreeing with the general direction of the NEB proposals took the position that the continuing interference in the marketplace by U.S. regulatory bodies such as the FERC and the California Public Utilities Commission ("CPUC") rendered it inappropriate to make the changes at this time.

As of May 22, 1992 no decision had been released.

\section{(ii) Rolled-in vs. Incremental Tolls}

It is likely that the Industrial Gas Users Association will raise the issue of rolled-in versus incremental tolls at TCPL's 1993 toll application despite the strongly worded decision approving rolled-in tolls for TCPL's 1991/92 Expansion Project. ${ }^{110}$

\section{(iii) Altamont Gas Transmission Canada Limited - Pipeline Construction}

On July 26, 1991, Altamont filed an application to construct a 300 metre long pipeline to be built by NOVA to connect to a proposed new pipeline in the U.S. Altamont requested that the NEB hold a comparative hearing between its application and one filed by ANG. The NEB denied the request and decided to proceed to consider each application on its own merits.

On April 15, 1992, the NEB wrote to Altamont's counsel stating that it intended to conduct a written procedure to determine the question of jurisdiction and whether the application of Altamont was properly brought before the NEB under section 58 of the National Energy Board Act. 
The question as set out in the NEB letter of April 15, 1992 is as follows:

Is the proposed pipeline of the applicant part of a larger extraprovincial undertaking to be constructed from a point near Empress. Alberta to a point of connection in the United States, the entire Canadian portion of which is subject to the jurisdiction of Parliament pursuant to section 92(10)(a) of the Constitution Act, 1867, having regard to the following factors:

(a) the physical connections between the pipelines of NOVA Corporation of Alberta ("NOVA"), Altamont Canada, and Altamont Gas Transmission Company;

(b) the operation of the NOVA and Altamont Canada pipelines as a line wholly or substantially dedicated to the export of a commodity from Canada; and

(c) the purposes to be served by the construction of the pipelines of NOVA and Altamont Canada?

This is yet another chapter in the competition between Altamont and PGT to transport natural gas to the California market.

(iv) Canadian Petroleum Association - Review of the GH-5-88 Reasons for Decision

This review is a continuation of the efforts to strike back at the actions of the CPUC.

The Canadian Petroleum Association ("CPA") made an application dated May 29, 1991, and amended on November 27, 1991, requesting that the NEB review its reasons for decision in GH-5-88 with respect to the issuance of gas export License GL-111 to Alberta and Southern Gas Co. Ltd. ("A\&S"). The CPA requested that the NEB:

(i) confirm the basis upon which it made its decision;

(ii) declare that the CPUC has acted in a manner contrary to Canadian and American energy policy, the Market Based Procedure, the GH-5-88 decision and the Free Trade Agreement; and

(iii) declare the basis upon which current and future decisions on gas exports and export-related pipeline construction will be based.

In its application, the CPA stated that current actions by the CPUC to implement capacity brokering on the PGT pipeline system were inconsistent with the NEB's decision in GH-5-88 "since it would abrogate the freely negotiated contractual undertakings upon which the GH-5-88 decision was based, would be contrary to the evidence that was relied on by the Board in reaching its decision, and would be inconsistent with the principles of Canadian and United States energy policy which formed the basis of this decision."

On November 27, 1991, following a November 14, 1991 decision by the CPUC to allow capacity brokering on the PGT system, the CPA filed an amended application. CPA said that the decision effectively directs Pacific Gas and Electric ("PG\&E") to terminate all long-term contracts with Alberta producers by October 1992. 
In amending its original application, CPA asked the NEB to vary all short-term export orders immediately to add a condition that prohibits deliveries into the pipeline system of PGT of any Canadian gas destined for utilization in the Northern California market that is not gas presently contracted by A\&S for sale to PGT. It adds that the condition should continue in full force and effect until the NEB has held a hearing, made its findings and rendered a decision in respect to the CPA application.

On February 4, 1992, the NEB decided, with respect to interim measures, that, effective immediately, the NEB will require any company planning to export additional gas under existing short-term orders at the Kingsgate, British Columbia export point to obtain prior permission of the NEB. This requirement will also apply to applicants for new short-term export orders. Affected companies will be required to file information relating, among other things, to pipeline systems to be used, the destination of the gas and the ultimate end-use customer. The NEB interim action in this case will enable it to monitor and, if appropriate, control such short-term gas exports.

The NEB also immediately suspended the right of A\&S to release or transfer any part of the firm capacity that it now holds on ANG's pipeline system. The interim action taken by the NEB will ensure that brokering does not take place on the ANG line without leave of the NEB.

These interim measures were directed at preventing short-term export arrangements from potentially displacing exports under long-term contractual arrangements. They will not restrict the total amount of exports currently authorized by the NEB nor the ability of the Northern California market to receive Canadian natural gas.

In addition, retaliatory action was taken by the Alberta government in the NOVA Terms of Service Regulation ${ }^{\prime \prime \prime}$ which, effective March 1, 1992, limited the availability of interruptible service on NOVA at the Alberta/British Columbia delivery point.

A three week hearing was held, commencing February 24, 1992. Apart from an attempt by the CPA to compel the production of witnesses by the CPUC, PG\&E and PGT, the hearing focused mainly on measures to prevent sales made under short-term orders from displacing sales made by Canadian producers contracted to A\&S/PGT/PG\&E in Northern California.

As at May 22, 1992 a decision had not been released.

In the meantime, senior officials from Canada, Alberta and B.C. began negotiations with officials from the U.S. government, California and the CPUC: ${ }^{12}$

If these negotiations do not find a political solution, the regulatory war will play itself out. The NEB has said it will refuse to authorize any spot-price exports to California that displace the existing long term

112. J. Shiry, CPA Review, Volume XVI, Number I, May 1992 at 6. 
exports. The board could also refuse to allow permits for gas on the PGT expansion unless regulatory interference into interstate and international contracts by the CPUC ceases. That would re-establish the role of both the NEB and FERC in regulating the terms of the international and interstate gas trade.

The real irony is that the CPUC's actions may be generating counter-measures by the Alberta government that are inappropriate under deregulation.

\section{(v) RH-2-91 Interprovincial Pipeline Inc. -1992 Toll Application}

Hearings were held from December 2, 1992 to February 21, 1992.

The matter which received the greatest attention was the tolling methodology for the Sarnia - Montreal pipeline, both in its current idled state and in the scenario line-reversal.

A study conducted in 1991 by the NEB at the request of the Minister of Energy Mines and Resources into the potential closure or reversal of the Sarnia-Montreal crude oil pipeline concluded: ${ }^{113}$

The major economic driving force for reversal of the Sarnia-Montreal pipeline is its potential to provide reliable competitive overseas crude oil supply to Ontario refineries. Without this supply, Ontario refiners will have to compete against land-locked American refiners for diminishing supplies of Canadian crude oils, particularly the lighter grades. Their ability to respond to increased feedstock prices may be limited by the poor profitability of the Ontario refining industry and competition from petroleum products imported from the United States.

The timing of a reversal, if shown to be required, will depend on individual companies' decisions as to the best means secure feedstock supplies. The IPL toll methodology is a critical element in assessing reversal economics.

Three weeks of the hearing were spent discussing toll methodology for the SarniaMontreal extension. IPL took the position that the Sarnia-Montreal extension is an integral part of its entire pipeline system and proposed that the tolls be structured accordingly. The Ontario refiners pressed for the reversal of the line to provide an economic feedstock supply option, provided that the "stand-alone" toll methodology which they were proposing was adopted. The Western Canadian producers proposed a "standalone" toll, but calculated by recapitalizing the extension to reflect a 3 percent depreciation rate, rather than the 5 percent permitted in the Deficiency Agreement between IPL and the federal government entered into at the time of construction of the line.

Since toll methodology is the most important aspect in the economics of line reversal for the Ontario refiners, they requested an early decision on tolling for the SarniaMontreal extension.

113. The Sarnia-Montreal Pipeline, A Review and Report by the National Energy Board, April 1991 at 1 . 
As at May 22, 1991 the decision of the NEB has not been released.

\section{Competition Tribunal/ Bureau of Competition Policy}

\section{(a) Decisions}

There were no new decisions relating directly to the oil and gas industry.

(b) Published Policy Statements

\section{(i) Price Discrimination}

A Discussion Paper on price discrimination was issued by the Director in July 1990; the deadline for comments was February 1992. No date has been set for the final draft.

\section{(ii) Mergers}

The final version of the Bureau's Merger Enforcement Guidelines was released in April 1991.

\section{Investment Canada - Published Policy Statements}

Modification of the federal government's policy restricting sale of Canadian controlled oil and gas assets to foreign investors was announced by The Honourable Jake Epp, Minister of Energy, Mines and Resources Canada: ${ }^{14}$

...there will no longer be a requirement to ensure Canadian ownership of 50 per cent of the upstream oil and gas industry through the Oil and Gas Acquisitions Policy.... Investment Canada reviews of transactions involving the acquisition of Canadian oil and gas assets by foreign interests will be conducted on the same basis as transactions in almost every other sector of the economy.

For US investors, the thresholds triggering Investment Canada review of direct oil and gas acquisitions will be raised to $\$ 150$ million. This is the same review threshold that applies to investment in other sectors under the Free Trade Agreement. Thresholds applying to all other foreign investors will remain at $\$ 5$ million for direct acquisitions and $\$ 5$ million for indirect acquisitions. With these changes, oil and gas will be treated exactly the same under the Investment Canada review process as any other sector.

114. The Honourable Jake Epp (Speech to Calgary Chamber of Commerce, Calgary, Alberta, March 25, 1992). 


\section{B. ALBERTA}

\section{Energy Resources Conservation Board}

\section{(a) Decisions}

\section{(i) Decision D $91-1^{115}$}

Polaris Petroleums Ltd. ("Polaris") applied for a licence to drill an exploratory well directionally to a bottom-hole location in another section. The owner of the surface above the target location intervened to oppose the application, having failed to reach agreement on the terms of a lease for a vertically drilled well. The surface owner expressed concern regarding various environmental matters, including the possibility of ground water contamination, but stated that one vertical well drilled under conditions he was prepared to impose would be preferable to allowing a horizontal well. Reference was also made to the possibility that, if the horizontal well proved successful, Polaris would drill more wells from the same site.

The ERCB disagreed with the intervener regarding the impact of individual vertically drilled well sites versus a multi-well pad location; the Board questioned the intervener's claim that the proposed well would have any effect upon his land and operations. Further, it was the Board's opinion that the applicant's proposed practices were an improvement upon normal oilfield practices. However, the Board took note of the many regional concerns for air, soil and groundwater protection and stated the belief that the concerns warrant further attention through industry representatives working with representatives from the area.

\section{(ii) Decisions D91-2 (Interim) ${ }^{116}$}

In connection with proposed construction of pipelines, stream crossings were given early approval in order to allow timely approval by the Minister of the Environment. The facts are related in Decision D 91-2 which follows.

\section{(iii) Decision $D$ 91-2 117}

Pursuant to Part 4 of the Pipeline Act, ${ }^{118}$ Shell Canada Limited ("Shell") applied for a permit to construct nine kilometres of pipeline in connection with production from a well. In total, seven creek crossings were contemplated.

\footnotetext{
115. Energy Resources Conservation Board Decision D 91-1 dated I March 1991, in the Matter of an Application for Well Licence - Provost Field.

116. Energy Resources Conservation Board Interim Decision D 91-2 dated 9 April 1991, in the Matter of Applications for Permits to Construct Pipelines to Transport Sour Gas and Fuel Gas - Waterton Area.

117. Energy Resources Conservation Board Decision D 91-2 dated 21 May 1991, in the Matter of Applications for permits to Construct Pipelines to Transport Sour Gas and Fuel Gas - Waterton Area. R.S.A. 1980 , c. P-8.
} 
To allow further preparation, a number of interveners requested adjournment to a later date. The Board acknowledged that the hearing was held a relatively short time after advertising. However, the Board was of the view that the parties had had adequate time to prepare as consultations had been held for some time.

Opposing arguments were made regarding the desirability of producing from the well (and thus installing the pipeline) in the immediate future. One viewpoint was that expeditious depletion of the gas reserves in area was desirable so that the area could be reclaimed to its natural state with minimal delay. The interveners claimed the need for further fish and wildlife studies to determine environmental impact. The Board stated that Shell had the right to produce the subject well unless the associated environmental impacts were found unacceptable.

Major environmental concerns related to the creek crossings and their impacts on native trout populations, as well as general impact of the project on wildlife in the area. The ERCB stated: 19

The Board believes that restricted travel, attention by Shell personnel to design appropriate drainage control systems, and routine inspection of the effectiveness of this control should avoid any material impacts on Whitney Creek. The Board is satisfied that neither the pipelines nor the operation of the well will have long-term effects on fish wildlife in the area and believes that Shell can resolve shorter-term concerns with proper construction techniques and operational management.

The decision contains a discussion of various reclamation methods. The Board concluded with a strong endorsement of the process that had been developed in the region and the opportunity thus presented for all affected parties to resolve problems related to the proposed pipelines.

\section{(iv) Decision $D 91-3^{120}$}

Pointer Exploration Corp. ("Pointer") applied for a well licence to drill a sour gas well in a quarter section containing twelve homes as well as agricultural land. The applicant had previously met with residents to identify and address concerns. These included the potential for odors, effects on water supplies, increased traffic, noise, negative aesthetic impact, reduction of property values, and safety. The interveners argued that the well could be directionally drilled from an adjoining legal subdivision, thus allowing greater distance between the residences and the well site. Pointer raised several arguments regarding increased cost and greater frequency of servicing in the case of a directionally drilled well.

Because of the low $\mathrm{H}_{2} \mathrm{~S}$ release rate and the availability of an alternate egress for residents, the Board did not require a full emergency response plan although it did require the applicant to file an emergency preparedness plan prior to spudding the well. The

120. Energy Resources Conservation Board Decision D91-3 dated 30 April 1991, in the Matter of an Application for a Well Licence - Bantry Field. 
Board directed Pointer to adopt its recommended procedures to minimize impacts rather than requiring the well to be drilled from an alternate location, as the Board was unconvinced that the very small potential for reduction in impacts would be sufficient to warrant increased costs and potential for reduced recovery of oil associated with the alternate site. In addition, the Board stated its concern that drilling from the alternate site would simply transfer impacts to other residents.

As the interveners proposed a change in well spacing in connection with directional drilling, criteria for changing well spacing were discussed. Having regard to conservation of the resource, potential surface impacts, potential affected parties, and the need for a change in spacing, the Board did not consider the interveners' proposal to be a viable alternative to the applicant's proposal.

\section{(v) Decision D 91-61 121}

Several applications relating to operations under the Leduc gas cap blowdown project were considered in this Decision. The Imperial Pipeline Company, Limited and Esso Resources (1989) Limited ("Esso Resources") applied for various permits and amendments to pipeline licences required to allow conversion of portions of the Edmonton to Sundre Expansion Pipeline ("ESEP") from crude oil (bitumen blend) to natural gas.

The Board considered the major issues to be: the need to accommodate excess Leduc gas, need for the ESEP conversion, transportation of blended crude bitumen, and economics. Pursuant to a 1984 ERCB decision, Esso Resources had the obligation to maintain certain gas production rates. In addition, Esso Resources presented evidence that the conversion would allow transportation of gas from future blowdowns. Upon receiving evidence that the rate of take by a purchaser was lower than the required production rate, the ERCB did not question the need to accommodate the excess. The Board focused on various considerations relating to orderly and efficient depletion and optimum recovery of the gas reserves, as well as to providing the greatest operating flexibility to manage gas reserves and EOR schemes, in finding that the conversion was needed.

The ESEP was operated as a common carrier; however, no serious interest in usage had been expressed by other parties. Thus, the Board's position was that the ESEP could be removed from blend service without significant adverse effects on the provincial pipeline network for crude oil or blend transportation. Issues of economics and public interest were addressed. Of particular interest is the discussion of security of supply for the Edmonton region and the role of Northwestern Utilities Limited in providing that supply.

An Addendum to this Decision was issued on 28 February 1992. After issuance of the original Decision, the Board reopened the hearing to receive representations from an intervener who claimed that he had not been given proper notice of the original hearing. The intervener expressed concern over the noise levels and lighting required by a 
proposed compressor station. After hearing evidence of Esso Resources' site selection process and proposed mitigative and monitoring measures, the ERCB noted that the ERCB Noise Control Directive was not a guarantee that residents would hear no sound from a facility. However, the operator must take necessary measures to ensure that the sound levels are kept within the range permitted by the Directive.

\section{(vi) Decision $D$ 91-7 122}

Pursuant to Part 4 of the Pipeline Act, ${ }^{123}$ Mid-west Gas Transmission Ltd. ("Mid-West") applied for a permit to construct 30 kilometres of raw gas pipeline from an existing gas plant to its existing Industrial Gas System. At a public hearing, the application was opposed by Northwestern Utilities Limited; however, upon completion of cross-examination of the Mid-West evidence, the objection was withdrawn. The intervener stated its belief that there should be close scrutiny of pipeline proposals to minimize duplication of facilities and to ensure sufficient reserves to support the facility.

On the basis of the evidence presented and withdrawal of the objection, the Board approved the application.

\section{(vii) Decision $D 91-8^{124}$}

Home Oil Company Limited, on behalf of itself and Scurry-Rainbow Oil Limited (together called the "applicant"), applied for several Board orders considered necessary in connection with its capped gas well ("4-9 well") adjacent to a proposed Hamburg Slave Point A Pool Unit. The decision provides considerable insight into the various issues arising in a unitization proposal. The various working interest owners were not opposed to including the 4-9 well in the unit; however, the main issues were the determination of the A Pool boundary and thus the tract participation to be assigned, the capacity that the applicant would receive at the Shell Hamburg Plant, and the timing of access to the plant. In any case, the applicant was concerned about drainage from the two producing wells in the A Pool. The applicant contended that, as it had been unable to reach agreement with the proposed unit working interest owners, it was necessary to apply for a rateable take order, an order declaring Shell Canada Limited to be a common processor, approval of a two-section drilling spacing unit for the 4-9 well, approval to construct the necessary pipeline to the Shell plant and a fuel gas pipeline from the gas plant to well.

The decision illustrates the variety of technical interpretations and thus the issues that can arise with respect to delineation of a pool. The Board considered the evidence and then proceeded to set out its definition of the A Pool. 
With respect to a common processor declaration, the ERCB stated: ${ }^{125}$

The Board considers that an applicant requesting a common processor declaration would be required to demonstrate to the Board's satisfaction that:

- producible gas reserves exist and gas processing facilities are needed;

- reasonable arrangement for the use of processing capacity in the existing plant could not be agreed on by the parties; and

- a common processor order represents the most economically feasible and desirable method to process the gas in question.

The Board rejected an argument that, if a rateable take order were issued, a common processor order would not be necessary and then proceeded to issue the common processor order.

The applicant submitted that, in view of negotiations that had already occurred, it had no alternative but to apply for a rateable take order to ensure an equitable share of gas from the A Pool. It proposed allocation on the basis of a validated-area approach. Various approaches were discussed by the interveners. In granting the rateable take order, the ERCB set out its criteria: ${ }^{126}$

The Board considers that an applicant requesting an order distributing production among wells in a pool would be required to demonstrate to the Board's satisfaction that it is being deprived of the opportunity to obtain its share of the production from the pool. The Board would determine whether or not the applicant has and will continue to have a reasonable opportunity to produce gas in proportion to the reserves associated with its well. The applicant must show that drainage is actually occurring as a result of the applicant not having an opportunity to produce its share of gas.

The decision discusses the issue of possible duplication of intended effects of a common processor order with those of a ratable take order, as well as the technical aspects relating to determining an appropriate rateable take formula.

The applicant applied for a special two-section drilling spacing unit (sections 8 and 9) for the off-target 4-9 well and stated its reasons for drilling the well off target. It contended that the well would be more than capable of draining the reserves underlying both sections. In stating its approval of the application, the Board considered the relevant matters to be: ${ }^{127}$

- whether the proposed special spacing would adversely affect the recovery of gas from the A Pool; 
- whether the proposed special spacing would represent an economic and efficient use of resources; and

- whether the special spacing would have any unacceptable effects on another party's opportunity to recover its share of gas from the A Pool.

With regard to construction of the pipelines, the Board was prepared to approve the applications and agreed that, if unitization does not proceed, the application would require the proposed pipelines to allow competitive production of the 4-9 well.

\section{(viii) Decision D 91-9128}

An application by Strathfield Oil \& Gas Ltd. for a well licence and production facilities was originally opposed by an intervener, at whose request a public hearing was postponed in order to allow him to obtain witnesses. At the hearing, the ERCB's jurisdiction, mandate, and qualifications in matters of agriculture and environment were questioned. The ERCB approved the applications on the basis of its view that: no specific evidence in opposition to the applications was presented, all the Board's requirements were met, and there was a need for the requested facilities.

\section{(ix) Decision D $91-10^{129}$}

Norcen Energy Resources Limited ("Norcen") applied for a licence to drill a well directionally from a surface location in legal subdivision ("LSD") 6 to a bottom-hole location in LSD 16 of the same section. Interveners consisted of a resident of LSD 12 and the owner of the northwest quarter. Norcen had failed to agree with the owner as to the compensation details of the surface lease in order to drill from LSD 11. Norcen then entered into a lease for the LSD 6 location. The interveners argued that the site in LSD 11 was on balance more desirable because of the proximity to the LSD 12 residence of the newly proposed access road. The well licence for LSD 6 was granted. The decision does not compare directly the two alternative locations. Rather, the Board seems to have focused on the acceptability of the LSD 6 location: "to assess the appropriateness of the well and access road location, the Board considered how the interveners would be affected and what mitigative measures, if any, are available to reduce any impacts to an acceptable level." ${ }^{130}$

An Addendum dated 21 November 1991 has been issued to identify two minor corrections to the text. However, the corrections have no impact on the decision.

Energy Resources Conservation Board Decision D 91-9 dated 22 July 1991, in the Matter of Applications for Well Licence and Permits to Construct Pipeline and Satellite Production Facility Provost Field. 


\section{(x) Decision $D 91-13^{131}$}

Polaris Petroleums Ltd. ("Polaris"), representing working-interest owners in a proposed gas-cap unit, applied for review and amendment of an Approval granted in 1977 under which gas-cap production was permitted from oil wells only, and each well would be subject to a specified MRL with a GOR penalty calculated on the basis of regulations. The application was made on the basis that continued production of gas under the Approval fails to afford the gas-cap owners the opportunity to obtain their share of gas production from the Joarcam Viking Pool. At the hearing, the applicant requested rescission of the Approval pursuant to section 42 of the Energy Resources Conservation $A c t^{132}$ claiming that the Approval fails to protect the interests of the gas-cap owners outside of the Approval area. Polaris submitted that attempts to unitize the gas cap will be stalled until the Approval is terminated.

Interveners presented a wide range of views on possible drainage and gas-in-place estimates. Evidence was presented that rescission of the Approval would result in shutting in oil wells. Reinjection of gas-cap gas was presented as one alternative to shutting in oil wells until an acceptable concurrent-production scheme could be devised.

Acknowledging the complexity of the question of drainage, the Board concluded that volumes of gas-cap gas from outside the Approval area had moved into the area and therefore drainage was a legitimate concern. However, the ERCB was reluctant to rescind the Approval and stressed the importance of achieving an economic and orderly development: ${ }^{133}$

...it would be better to retain the Approval in some altered form than to rescind or suspend it. Rescinding the Approval could result in complete shut-in of production from the Approval area of any well that has a producing GOR significantly exceeding the solution GOR. The Board believes that this would effectively shut in the oil production and gas conservation facilities in the Approval area.

The Board altered the Approval by imposing a lower MRL of oil subject to a specified GOR penalty base, stating that this would reduce the gas-cap production and still permit oil recovery from the Approval area. Furthermore, this would permit continued operation of the gas conservation facilities, as well as encouraging the parties to reach agreement on unitization and production schemes. The ERCB stated its intention to continue review of operations under the modified Approval to determine whether further modifications are appropriate.

This decision illustrates the reluctance of the Board to shut in facilities that have commenced production under a Board Approval or to substitute Board solutions for cooperation and agreement among producers.

131. Energy Resources Conservation Board Decision D 91-13 dated 7 October 1991, in the Matter of an Application for Rescission of Board Approval No. 2534 - Joseph Lake Area - Joarcam Viking Pool. 


\section{(xi) Decision D $91-15^{134}$}

Bow River Pipe Lines Ltd. applied for various permits in connection with a proposed pipeline system to transport heavy crude to Montana markets. The only interveners were other producers and pipeline operators either supporting or opposed to the application.

Opponents presented arguments that the new upgraded system would render other existing facilities redundant and expressed concerns about resulting tariffs. The main position of supporters was that the proposed system was required to meet the expanding market.

This Decision illustrates the complex relationships among area producers, pipeline operators, and potential purchasers of product that must be addressed in proposals for changing or developing a pipeline system.

(b) Published Policy Statements

The ERCB regularly issues Informational Letters and Interim Directives on a variety of operational matters. The ERCB issued Interim Directives 91-1 through 91-6 in 1991. Due to space limitations, summaries of Informational Letters are provided only for those of possible interest to oil and gas lawyers.

\section{(i) Informational Letter IL $91-2^{135}$}

This document summarizes the Board's requirements for the temporary flaring of sour gas. Thus, it provides an explanation of the reasons for recent changes in Oil and Gas Conservation Regulations.

\section{(ii) Informational Letter $91-3^{136}$}

In this letter, the Board emphasizes the importance of filing S-4 Forms immediately upon a change in well status. In the case of multiple completions, a separate form is required for each producing zone. Failure to submit timely and accurate reports creates difficulties not only for the ERCB, but also for the Department of Energy and the industry at large.

134. Energy Resources Conservation Board Decision D 91-15 dated 10 February 1992, in the Matter of an Application for Permit to Construct a Crude Oil Pipeline and Pumping Facilities - Southern Alberta.

135. Energy Resources Conservation Board Informational Letter 91-2, "Sour Gas Flaring Requirements and Changes to Regulations," 7 March 1991.

136. Energy Resources Conservation Board Informational Letter 91-3, "Well Production Records and S-4 Submissions," 15 February 1991. 


\section{(iii) Informational Letter IL $91-7^{137}$}

In this document, the Board describes revisions to requirements set out in a 1975 Informational Letter IL-OG 75-13. Revisions were required because conditions affecting production from certain southeastern Alberta gas pools have changed.

\section{(iv) Informational Letter $91-9^{138}$}

The Oil and Gas Conservation Regulations require applications from operators seeking exemption from the measurement of gas produced a crude oil or crude bitumen well. The Board now states: ${ }^{139}$

The Board has decided to discontinue the requirement for these applications for those situations where the exemption criteria as described within this information letter are met, with the intent of reducing the administrative workload of both Industry and the Board. Although the requirement for application has been removed, the Board's expectations regarding gas measurement remain essentially the same. Eligibility criteria for exemption from gas measurement, and in the Board's expectations of the respective operators, are described in the remainder of this informational letter.

Existing Regulations are to be amended.

\section{(v) Informational Letter $91-10^{140}$}

The ERCB issued a reminder that licensees must obtain its permission to perform wellbore and zonal abandonments and plugback operations at wells. Guide G-20, the Drilling and Completion Operations Guide, is available through the ERCB's Information Services Section. It reflects recent changes to policy and requirements.

\section{(vi) Informational Letter $91-11^{141}$}

The ERCB provides preliminary regulatory provisions which are to apply to any evaluation or production of coalbed methane until appropriate regulatory policies based on Alberta information may be formulated. A task group is to be established to monitor coalbed methane evaluation and development. The ECRB states that the Alberta Department of Energy and the Board consider coalbed methane to be a form of natural gas. Although policies relating to the drilling and production of conventional gas reservoirs can be applied directly to coalbed methane, this letter sets out some specific details regarding various operational matters such a drilling and data requirements.

137. Energy Resources Conservation Board Informational Letter 91-7, "Revised Measurement and Accounting Procedures for Southeastern Alberta Shallow Gas Wells," 12 September 1991.

138. Energy Resources Conservation Board Informational Letter IL 91-9, "Exemption from Gas Measurement - Crude Oil/Bitumen Wells," 17 July 1991.

139. Ibid. at 1 .

140. Energy Resources Conservation Board Informational Letter 91-10, "Requirements for Abandonments and Other Drilling and Completion Operations: Guide G-20," 30 August 1991.

141. Energy Resources Conservation Board Informational Letter 91-11, "Coalbed Methane Regulation," dated 26 August 1991. 
(c) Evolving Matters

\section{Review of NOVA Pipeline System Operation}

On June 21, 1991, the Alberta Minister of Energy requested the ERCB to carry out a review of the operation of the NOVA transmission system to identify and clarify existing problems and methods of addressing these problems. The review was triggered by concerns expressed by industry representatives centring on the management of the system and the associated cost of transporting natural gas. After receiving submissions, the ERCB prepared a Summary of Issues dated November 4, 1992, and requested a response from NOVA and those who made submissions. As of May 22, 1992 a final report had not been released.

At page 3 of the Summary of Issues, the ERCB provided an Overview of Submissions as follows:

There was considerable agreement that some aspects of NOVA's operations were favourable and should be maintained for example, availability of access to the system on common terms and the high degree of reliability of gas delivery. On the negative side, most parties expressed concern about the rising cost of shipping gas on NOVA's system. A number of possible reasons for rising costs were identified, also as discussed in section IV of this summary. A second apparent area of general dissatisfaction was that NOVA's operational and decision-making criteria are not well set out or understood by most users of the system. Some submitters indicated they simply did not have access to sufficient information to allow them to determine whether or not their concerns about costs, for instance, were justified.

A final area raised by many submitters was whether the regulatory framework under which NOVA currently operates is appropriate. Although there were diverse views on this question, most submitters aligned themselves with one of six alternate approaches to regulation of NOVA. These approaches range from the status quo to significantly increased regulatory oversight; these are set out in detail in section IV.

The results of this review will be of much interest to the gas industry, especially if the review recommends changes in regulatory oversight.

\section{Alberta Public Utilities Board Decisions - Evolving Matters}

NOVA Corporation of Alberta

RE 91094, 91095, 91096

Complaints filed by the Alberta Gas Producer Group, the Independent Petroleum Association and the Canadian Petroleum Association alleging that NOVA's rates, toll or charges to be charged to customers effective January 1, 1992 are not just and reasonable.

As a result of the inability of the Alberta Gas Producer Group and NOVA to negotiate an acceptable rate of return and associated deemed common equity for NOVA, complaints were filed objecting to NOVA's requested return of $13.5 \%$ on $35 \%$ deemed common 
equity. A hearing has been scheduled by the PUB to begin July 13, 1992 in Calgary to review the complaints.

\title{
3. Alberta Natural Resources Conservation Board
}

In April 1992, the NRCB announced that the Board's offices would be moved from Calgary to Edmonton; no date was set for the move. The newly constituted NRCB has held no hearings of direct application to the oil and gas industry. In conjunction with Regulations regarding funding for eligible interveners, guidelines respecting claims for eligible intervener costs awards were issued in July 1991. On October 16, 1991, rules of practice for the NRCB were issued.

\section{BRITISH COLUMBIA}

\section{(a) Decisions}

\section{(i) BC Gas Inc. - Rate Design Application}

This hearing was the first phase of gas re-regulation in B.C. Gas sales in 95 percent of the domestic market having been unregulated for the three years prior to October 1, 1991. A series of hearings is planned to develop an integrated tariff for use throughout the BC Gas system.

\section{The British Columbia Utilities Commission ("BCUC") outlined its task: ${ }^{142}$}

\begin{abstract}
The requirements of the regulated monopoly transportation system are not fully compatible with the characteristics of competitive markets at the wellhead and the greatest challenge facing regulatory tribunals is to deal with the needs of both systems at their interface so that consumers are provided a high quality service at competitive prices.
\end{abstract}

The BCUC was concerned that sales prices to the Core Markets should be reflective of the gas supply costs, and that the allocation of supply costs must reflect competitive market prices. The dilemma is that BC Gas' industrial load is interruptible with minimal curtailments and the customers are dual fuel, whereas the field contracts are for firm gas supply at high load factors.

The hearing heard proposals for an auction to enable BC Gas to sell gas that is excess to its basic requirements on an interruptible basis. The BCUC considered it premature to make a decision on the auction plan which had evolved rapidly during the hearing, so it directed BC Gas to resubmit its auction proposal by July 15, 1992.

The decision was released on February 21, 1992. 


\section{(ii) British Columbia Hydro and Power Authority - Rate Design Application}

The decision of BCUC was released in April, 1992.

This hearing was presented with a radical proposal for rate design for the industrial sector which was designed to encourage users by means of price, to use alternative means of power supply which would in the long run be cheaper than to the cost to B.C. Hydro of building a new hydro project.

The BCUC directed B.C. Hydro: ${ }^{143}$

...to work with its industrial customers and with Power Smart to develop a cohesive package of incentive programs and rate incentives to acquire efficiency and conservation energy savings for Industrial customers at least cost to the Utility. This work must begin with the gathering of data on each industrial customer's operation to identify economic savings and methods of attainment of load reductions. A progress report on B.C. Hydro's findings is to be filed with the Commission by January, 1. 1993.

This directive may open up opportunities for cogeneration facilities, especially using gas.

(b) Evolving Matters

(i) BC Gas Inc. - Rate Design Application (Phase 2)

All remaining rate design issues not dealt with in Phase 1 are scheduled to be heard in September, 1992. 